\title{
Effect of Acacia purified tannins extract and polyethylene glycol treatment on in vitro ruminal fermentation pattern and methane production
}

\author{
Khaoula Khelalfa ${ }^{a^{*}}$, Rabah Arhab ${ }^{\mathrm{b}}$, Antonio Ignacio Martín-García ${ }^{\mathrm{c}}$, Nabila Zaabat ${ }^{\mathrm{d}}$, Alejandro Belanche \\ ${ }^{a}$ University of Mentouri Brothers, Department of Biochemistry and Cell and Molecular Biology, Faculty of Nature and Life Sciences, BP, 325 \\ Ain El Bey Road, Constantine, Algeria \\ ${ }^{b}$ Faculty of Exact Sciences and Natural and Life Sciences, University of Larbi Ben M'Hidi, Oum El Bouaghi, Algeria \\ 'Estación Experimental del Zaidín (CSIC), Camino del Jueves s/n, 18100 Armilla, Granada, Spain \\ ${ }^{d}$ Laboratory for V alorization of Natural Resources, Bioactive Molecules and Phytochemical and Biological Analysis, University of Mentouri \\ Brothers, Constantine, Algeria
}

Received 15th December 2019 / Accepted 11th April 2020

\begin{abstract}
Condensed tannins are polyphenolic compounds which can exert beneficial effects in ruminants. They have the ability to bind proteins and decrease their degradation. They have also been reported to reduce methanogenesis and improve ruminants performances. The present work aimed to study the effect of purified condensed tannins from Acacia horrida extract on fermentation parameters, gas and methane production. In this context, seven substrates were selected: four Acacia species (Acacia pycnantha, Acacia dealbata, Acacia horrida and Acacia cyanophylla) and three plant by-products (date palm leaves, grenade peel and artichoke stems). Biological activity of tannins was evaluated by the incubation of the substrates in vitro with Polyethylene glycol (PEG). Tannins decreased concentration of all fermentation parameters (gas $(\mathrm{p}<0.0001)$, methane $\left(\mathrm{CH}_{4}\right)(\mathrm{p}=0.0983)$, ammonia $\left(\mathrm{N}-\mathrm{NH}_{3}\right)(\mathrm{p}=0.0382)$, Volatile Fatty Acids $(V F A)(p=0.0009)$, acetate $(p<0.0001)$, propionate $(p=0.1024)$, butyrate $(p=0.0373)$, isobutyrate $(p=0.0046)$, valerate $(p<0.0001)$, isovalerate $(p=0.0032))$. Substrates were also characterized by their content in main nutrients (dry matter $(\mathrm{DM})$, organic matter $(\mathrm{OM})$, ash, crude protein $(\mathrm{CP})$, neutral detergent fiber (NDF), acid detergent fiber (ADF), acid detergent lignin (ADL)) and in secondary metabolites (total phenols (TP), total tannins (TT) and condensed tannins (CT) ). All substrates presented high CP content except by-products $(>100 \mathrm{~g} / \mathrm{kg} \mathrm{DM})$ and moderate cell-wall components. CT content was comprised between 120.5 and $680.4 \mathrm{~g} / \mathrm{kg}$ DM in plants and between 23.1 and $170.4 \mathrm{~g} / \mathrm{kg}$ DM in plant by-products. $A$. horrida presented the highest biological activity. Thus, their CT were extracted and purified on a sephadex LH-20 column. Purified tannins from $A$. horrida were incubated with two different forages alfalfa hay and barley straw at three different concentrations: 50,100,150 mg/g DM. Results showed that purified tannins from $A$. horrida had no effect on fermentation parameters ( $\mathrm{P}>0.05)$. The effects of $A$. horrida tannins may be strongly linked to their structure and their molecular weight more than to their concentration. For this reason, it is interesting that this work may be completed by physical characterization of these tannins.
\end{abstract}

Keywords: Acacia borrida, Acacia spp., plant by-products, purified tannins

*Author for correspondence: Khaoula Khelalfa, University of Mentouri Brothers, Department of Biochemistry and Cell and Molecular Biology, Faculty of Nature and Life Sciences, BP, 325 Ain El-Bey Road, Constantine,

Algeria. Email - khaoula-kh@live.com 


\section{INTRODUCTION}

Tannins are secondary metabolites with high molecular weight (Hao et al., 2011) which are widely distributed in plants. Their principal role consists on defense against herbivore predators, and microorganisms (Sliwinski et al., 2002). They are divided into two groups condensed tannins and hydrolysable tannins (Krueger, 2010; Naumann et al., 2017).

In ruminant's nutrition, tannins can have beneficial and harmful effects; harmful effects are due to their ability to bind to macro-moieties mainly proteins (Ningrat et al., 2016; Naumann et al., 2018). They are considered as antinutritional factors that decrease feed intake and nutrient digestibility (Bravo, 1998; Goel et al., 2005; Mezzomo et al., 2011). However, tannins have been reported to modulate fermentation pattern, inhibit methanogenesis, reduce ruminal protein degradation and, consequently, increase its outflow to the intestine (Frutos et al., 2004 ; Liu et al., 2011; Patra and Saxena, 2011) indirectly by proteolytic enzymes inhibition (Makkar, 2003) and/or directly through their molecular coating; via the formation of tannins-proteins complexes. This application represents a biotechnological pathway to improve animal production.

The present work aims at highlighting this biotechnological pathway, thus seven substrates rich in tannins were selected: four plants (Acacia pycnantha, Acacia dealbata, Acacia horrida and Acacia cyanophylla) and three plant by-products (date palm leaves, grenade peel and artichoke stems). Acacia species are leguminous shrubs commonly found in the arid and semi-arid zones of Algeria. They are adapted to low rainfall, drought and soil salinity of these regions. They are generally rich in proteins, energy and minerals. They produce wood, edible seeds, valuable gums and can provide important protein supplements in ruminant's nutrition especially during the dry season when fresh fodder availability is limited ( Fikri Benbrahim et al., 2014). Likewise, plant byproducts containing tannins can represent an important source of protein supplement in ruminants diet (Makkar, 2003). However, the potential use of these substrates as protein supplements for ruminants requires knowledge of concentration and biological activity of tannins since these antinutritional factors can cause negatives effects on ingestion and digestibility (Makkar, 2005). Thus, the objectives of the present work were: (1) to evaluate the biological activity of substrates by the in vitro gas production method in presence of PEG, the nutrient composition and anntinutritonnel factors content. (2) to study the effects of purified condensed tannins extract from the substrate with the highest tannins biological activity on ruminal fermentation pattern and methane production.

\section{MATERIALS AND METHODS}

The study was carried out at the Department of Biochemistry and Cell and Molecular Biology, Faculty of Nature and Life Sciences, University of Mentouri Brothers, Constantine, Algeria and at the Zaidin Experimental Station, Granada, Spain from February 2018 to February 2019.

\section{Experimental substrates}

Seven substrates were studied: leaves from four plants species (Acacia pycnantha, Acacia dealbata, Acacia borrida and Acacia cyanophylla) and three plant by-products: date palm (Phoenix dactilyfera) leaves, artichoke (Cynara scolymus) stems and promegranate (Punica granatum) peel. The plants leaves and the plant by-products were collected on February 2016 from semi-arid zones of the north east of Algeria. Date palm leaves were collected from arid zone. The samples were airdried and ground to calibrated particles of $1 \mathrm{~mm}$.

\section{Nutrients composition}

Substrates were evaluated for dry matter (DM), organic matter $(\mathrm{OM})$ according to the Association of Official Analytical Chemists (AOAC) (1990). Crude (CP) protein by Kjeldhal procedure, neutral detergent fiber (NDF), acid detergent fiber (ADF) and acid detergent lignin (ADL) were estimated following the procedure of Van Soest et al. (1991).

\section{Tannins extraction and purification Extraction}

An amount of $200 \mathrm{mg}$ of dried substrate were added to $10 \mathrm{ml}$ of acetone $70 \%$ (acetone: water, 70:30) and subjected to ultrasonic treatment in an 
Ultrasonic Processor (Bioblock Sientific vibracell $75043)$ for $20 \mathrm{~min}$ at ambient temperature $\left(25^{\circ} \mathrm{C}\right)$. The mixture was then centrifuged at $3000 \mathrm{x} g$ and $4^{\circ} \mathrm{C}$ for $20 \mathrm{~min}$. The supernatant was kept on ice and the pellet was resuspended in $10 \mathrm{ml}$ of acetone $70 \%$ and again subjected to ultrasonic treatment for $20 \mathrm{~min}$. The extraction was repeated until the supernatant become colourless indicating the end of extraction process (Makkar et al., 1993).

\section{Total phenols and tannins determination}

Total phenols (TP) were determinate by FolinCiocalteu method. Total tannins (TT) were evaluated by the difference between the total phenols before and after treatment with tannins agent binding, the polyvinylpolypyrrolidone (PVPP) according to Makkar et al., (1993); a volume of $1.0 \mathrm{ml}$ of distilled water was added to $1.0 \mathrm{ml}$ of the extract and $100 \mathrm{mg}$ of PVPP, the mixture was kept at $4^{\circ} \mathrm{C}$ for $15 \mathrm{~min}$ then was centrifuged at $3000 \mathrm{x} \mathrm{g}$ and $4^{\circ} \mathrm{C}$ for $10 \mathrm{~min}$. Phenolic content of the supernatant (other than precipitated tannins with PVPP) was determinate by Folin-Ciocalteu method. Absorbance was measured at $725 \mathrm{~nm}$. TP and TT contents were expressed as tannic acid equivalent $(y=0005 x$, $\left.\mathrm{r}^{2}=0.9927\right)$.

Total Condensed tannins (TCT) were determinate by butanol- $\mathrm{HCl}$ method at $550 \mathrm{~nm}$ and expressed as catechin equivalent $(\mathrm{y}=0.3188$, $\mathrm{r}^{2}=0.9874$ ) (Porter et al., 1986).

\section{Purification}

An amount of $50 \mathrm{~g}$ of Acacia horrida leaves were extracted with $500 \mathrm{ml}$ of aqueous acetone $(70 \%+1 \mathrm{~g}$ ascorbic acid) with stirring for $40 \mathrm{~min}$. The mixture was filtered into vacuum flask with a porcelain funnel provided with filter paper $(\varnothing=$ $15 \mathrm{~cm})$. The filtrate $(250 \mathrm{ml})$ was then taken into a separating funnel and mixed with $250 \mathrm{ml}$ of dichloromethane. After decantation, the lower phase was discarded (containing pigments and lipids). However, the upper phase was washed again two times with dichloromethane. This phase was recovered and evaporated at $37^{\circ} \mathrm{C}$ to remove acetone, the aqueous residue was freeze dried (Terrill et al., 1992).

About $1 \mathrm{~g}$ of tannin extract was dissolved in methanol (50\%) and applied to Sephadex LH-20 column (length $13 \mathrm{~cm}$ and diameter $2.3 \mathrm{~cm}$ ) equilibrated with methanol (50\%). The column was washed with the same solvent $(650 \mathrm{ml})$ and then tannins were eluted with aqueous acetone $(70 \%, 450 \mathrm{ml})$. The eluates were checked by thinlayer chromatography (TLC). The fractions containing tannins were combined, rotary evaporated and kept on ice until use.

\section{In vitro gas production essay}

The study was divided into two experiments: the first was conducted to select the substrate with the highest tannins biological activity. This was assayed by adding polyethylene glycol (PEG) as tannins binding agent (Makkar et al., 1995). The second experiment was aimed to study the effect of purified tannins on ruminal fermentation parameters, gas and methane production.

\section{Animals}

Four female Murciano-granadina goats equipped with permanent rumen fistula were used as donors of rumen liquor for both experiments. Animals were kept in individual pens and had free access to tap water. They were fed of forage: concentrate (50:50 of alfalfa hay/concentrate) served in two equal meals twice a day at $08: 00 \mathrm{~h}$ and 16:00 $\mathrm{h}$.

\section{Rumen liquor}

Rumen juice presented the inoculum was collected before morning feeding from the four goats and immediately was taken in prewarmed thermal flasks to the laboratory, where it was strained through two layers of cheesecloth under a continuous stream of $\mathrm{CO}_{2}$ at $39^{\circ} \mathrm{C}$. Rumen juice was then mixed with prewarmed artificial saliva in a 1:3 proportion.

\section{Experiment 1: Screening of the substrate with the highest tannins biological activity}

In order to select the substrate with the highest tannins biological activity, amount of $400 \mathrm{mg}$ of each substrate without or with $1 \mathrm{~g}$ of PEG (MW 4000) were incubated with $40 \mathrm{ml}$ of medium culture (rumen fluid $(10 \mathrm{ml})+$ artificial saliva (30 $\mathrm{ml}$ )) in $120 \mathrm{ml}$ glass bottles (Theodorou et al., 1994). The bottles were incubated in water bath at $39^{\circ} \mathrm{C}$. For each substrate, four replicates were done. Under the same conditions, four blanks were incubated (medium culture without substrate). 


\section{Experiment 2: The effect of purified tannins on ruminal fermentation parameters, gas and methane production}

Different concentrations of purified tannins $(0$, $50,100,150 \mathrm{mg} / \mathrm{g}$ DM of forage) were added to $500 \mathrm{mg}$ of alfalfa hay (DM 91.0\%, OM 90.3\%, NDF $51.8 \%$, ADF $33.8 \%$, ADL $9.54 \%$, CP 19.7\%) and barley straw (DM 92.7\%, OM 93.7\%, NDF $64.5 \%$, ADF $38.1 \%$, ADL $6.65 \%$, CP $7.0 \%$ ) and $40 \mathrm{ml}$ of medium culture. Samples were incubated for $24 \mathrm{~h}$ at $39^{\circ} \mathrm{C}$.

\section{Gas and methane measurements and calculation}

The gas pressure in each bottle was recorded at 2, 4, 6, 12, 24 and 48 h using a Wide Range Pressure Meter (Sper Scientific LTD, Scottsdale, AZ, USA). The gas produced was adjusted to the monophasic exponential model $y=A *\left[1-e^{-\left({ }^{*} t\right)}\right]$ of France et al. (2000), where y represents the gas production (GP, $\mathrm{ml}$ ); $\mathrm{t}$ represents the time of incubation $(\mathrm{h})$; A represents the asymptote $(\mathrm{ml})$; and $\mathrm{c}$ represents the rate of gas production $\left(\mathrm{h}^{-1}\right)$. After $24 \mathrm{~h}$, a gas sample of $5 \mathrm{ml}$ from each bottle were taken and injected in evacuated tubes (Terumo Europe N.V., Leuven, Belgium) to determinate $\mathrm{CH}_{4}$ production by gas chromatography (HP Hewlett 5890 Packard Series II gas chromatograph, Waldbronn, Germany).

\section{Determination of ammonia and volatile fatty acids}

After $24 \mathrm{~h}, 0.8$ and $0.2 \mathrm{ml}$ of medium culture were taken from bottles then transferred to eppendorf tubes and added to $0.2 \mathrm{ml}$ of deproteinising solution $(4 \mathrm{mg} / \mathrm{ml}$ crotonic acid and $20 \mathrm{mg} / \mathrm{ml}$ of metaphosphoric acid dissolved in $0.5 \mathrm{M} \mathrm{HCl}$ ) for volatile fatty acids (VFA) determination and to $0.05 \mathrm{ml}$ of Trichloroacetic Acid (TCA, 25\%), for ammonia $\left(\mathrm{N}-\mathrm{NH}_{3}\right)$ determination. Samples were frozen at $-20^{\circ} \mathrm{C}$ until analysis. Before analysis, samples were centrifuged at $4000 \mathrm{xg}$ and $4^{\circ} \mathrm{C}$ for $20 \mathrm{~min}$. The VFA were analyzed by gas chromatography (Auto system Perkin-Elmer Cor., Norwalk, Connecticut, USA) following the procedure pronounced by Arco-Pérez et al. (2017). Ammonia was determined using the Colorimetric method of Weatherburn (1967).

\section{Statistical analysis}

Data was subjected to one-way analysis of variance (ANOVA-one way) using the SAS (Institute Inc, 2003). At $\mathrm{P}<0.05$, differences were estimated significant. When significant differences were found means were compared by the Tukey test.

\section{RESULTS AND DISCUSSION}

\section{Nutrient composition}

The nutrient composition of plants and plant byproducts is represented in Table 1. All Acacia species presented high CP content ranging from 178.0 to $201.6 \mathrm{~g} / \mathrm{kg}$ DM. Thus, these species can be used as protein supplement in the diet of ruminants feeding low quality forage (Makkar et al., 1995). The CP content recorded in Acacia species was comparable to the one found by Rubanza et al. (2005) and higher than the one found by Al-Soqeer (2008). Differences recorded between studies may be due to variations in the stage of growth, the part of the plant studied (twigs, leaves, stem, pods), the type of soil and season (Melesse et al., 2017).

Plant by-products presented low CP content ranged from 48.1 to $95.8 \mathrm{~g} / \mathrm{kg} \mathrm{DM}$. The highest amount was recorded in date palm leaves (95.8 $\mathrm{g} / \mathrm{kg}$ DM) and the lowest was recorded in Punica granatum peel $(48.1 \mathrm{~g} / \mathrm{kg} \mathrm{DM})$. The result recorded in date palm leaves was higher than those reported by (Pascual et al., 2000; Ziaei and Sharifi Hosseini 200; Boufennara et al., 2016). The CP concentration of Punica granatum peel was similar to those noted by (Shabtay et al., 2008; Sadq et al., 2016; Yurtseven et al., 2018) and higher than the one recorded by Mirzaei-Aghsaghali et al. (2011).

All Acacia species had high NDF and ADL contents, their concentration ranged between $379.1-553.9 \mathrm{~g} / \mathrm{kg} \mathrm{DM}$ and between 140.6-264.7 $\mathrm{g} / \mathrm{kg}$ DM, respectively. NDF results were similar to those found by Al-Soqeer (2008), whereas those of $\mathrm{ADL}$ were higher than those noted by the same author. The highest NDF content recorded in A. cyanophylla was comparable to those found by (Bensalem et al., 1997; Bensalem et al., 1999; Moujahed et al., 2000). The ADF content ranged from 109.5 to $353.7 \mathrm{~g} / \mathrm{kg}$ DM. The highest amount was noted in $A$. pycnantha which was 
comparable to the one found by Hanafy et al., (2014) and the lowest in $A$. horrida which was similar to the amount noted by Tefera et al., (2008). Variation in cell-wall components between Acacia species may be due to the stage of growth.

A considerable variation in cell-wall components was recorded in plant by-products. The highest amounts were recorded in date palm leaves; this can be attributed to the high temperature which generally favors accumulation of the cell wall structural materials (Abebe et al., 2012). The result of NDF was similar to the one observed by Pascual et al. (2000) and lower than the one noted by Boufennara et al. (2016). However, $\mathrm{ADF}$ and $\mathrm{ADL}$ contents were higher than those noted by the same studies.

\section{Phenolic compounds analysis}

Phenolic compounds composition of plants and plant by products is also represented in Table 1 . All Acacia species had high TP content; amounts ranged between 591.2 and $798.4 \mathrm{mg} / \mathrm{g}$ DM. They were also characterized by their high TT content which was greater than $300 \mathrm{mg} / \mathrm{g}$ DM. The TP and TT contents recorded in our study were similar to those obtained by Rubanza et al. (2005). Tested Acacia species had high TCT content, the highest amount was recorded in $A$. horrida $(680.4$ $\mathrm{mg} / \mathrm{g} \mathrm{DM})$ and the lowest was recorded in $A$. pycnantha $(120 \mathrm{mg} / \mathrm{g} \mathrm{DM})$. The amount recorded in $A$. pycnantha was similar to the one reported by Grainger et al. (2009) in Acacia mearnsii. Variation in phenolic compounds between studies may be due to stage of growth, the collection period of plants, extraction method and technique used to determine phenolic contents.

In plant by-products, TP and TT contents levels ranged between $585.9-799.2 \mathrm{mg} / \mathrm{g} \mathrm{DM}$ and between $351.3-517.9 \mathrm{mg} / \mathrm{g} \mathrm{DM}$, respectively. The highest amounts of both TP and TT were recorded in Punica granatum. Plant by-products showed low TCT content except date palm leaves which presented amount of $170.4 \mathrm{mg} / \mathrm{g}$ DM.

\section{Screening of plant with the highest tannins biological activity \\ Effect of tannins on gas production}

The effect of tannins on Gas Production (GP) is exposed in Table 2. The results showed that tannins affected GP in all substrates $(\mathrm{P}<0.0001)$.
In absence of PEG, the highest GP was recorded in C. scolymus stems $(159.8 \mathrm{ml})$ and the lowest in A. dealbata $(29.6 \mathrm{ml})$. However, in presence of PEG, the lowest GP was recorded in date palm leaves $(70.96 \mathrm{ml})$.

In plants, the largest effect of tannins was observed in $A$. dealbata. GP was increased by $210.16 \%$ in presence of PEG, followed by $A$. borrida (92.5\%), A. cyanophylla (40.7\%) and $A$. pycnantha (19.0\%) (Figure1). In plant by-products, the impact of tannins was more pronounced for C. scolymus stems $(27.6 \%)$ than grenade peel $(13.8 \%)$ and date palm leaves (1\%) (Figure 2).

Results showed that in absence of PEG, low GP was recorded in Acacia species particularly in A. dealbata, plant with the highest TT content determinate by chemical method. Low GP recorded in Acacia species can be attributed to the anti-nutritional effects of tannins, indeed tannins can bind to carbohydrates and inhibit their degradation and thus reduce GP, since GP is the result of carbohydrates degradation (Njida and Nasiru, 2010; Abdallah Hassan Sallam et al., 2010). This result was similar to the one reported by Bhatta et al., (2009), these authors noted that GP was reduced in samples containing tannins. Likewise, Rodriguez et al., (2014) reported that species with high tannins concentration showed the lower GP.

In plant by-products, the lowest GP was recorded in date palm leaves; by-product with the highest tannins content, but there was no increment in gas production with PEG inclusion suggesting the low biological activity of its tannins (Guerrero et al., 2012).

\section{Effect of tannins on methane production}

Tannins' effect on $\mathrm{CH}_{4}$ production is also exposed in Table 2. The results indicated that tannins influenced methane production differently among substrates. However, these differences were statistically comparable $(\mathrm{P}>$ 0.05). The highest $\mathrm{CH}_{4}$ reduction was observed in A. pycnantha $(54.5 \%)$. Tannins content of $C$. scolymus and $A$. horrida had no effect on methane production. 
Table 1. Nutrient composition and secondary compounds content of experimental plants and plant by-products expressed as $\mathrm{g} / \mathrm{kg}$ and $\mathrm{mg} / \mathrm{g}$ of dry matter.

\begin{tabular}{|c|c|c|c|c|c|c|c|c|c|c|c|c|}
\hline \multirow[t]{2}{*}{ Substrate } & \multicolumn{9}{|c|}{ Nutrient Composition } & \multicolumn{3}{|c|}{$\begin{array}{c}\text { Secondary compounds } \\
\text { content }\end{array}$} \\
\hline & DM & $\mathbf{O M}$ & Ash & $\mathbf{C P}$ & NDF & ADF & Hemicellulose & Cellulose & ADL & TP & TT & TCT \\
\hline A. borrida & 730.7 & 899.9 & 100.1 & 182.8 & 379.1 & 191.4 & 187.7 & 50.8 & 140.6 & 785.1 & 521.3 & 680.4 \\
\hline A. cyanopbylla & 632.4 & 881.0 & 119.0 & 186.6 & 553.9 & 253.3 & 300.6 & 80.8 & 172.5 & 778.7 & 442.3 & 439.7 \\
\hline A. dealbata & 623.9 & 950.1 & 49.9 & 201.6 & 429.4 & 238.3 & 191.1 & 73.2 & 165.1 & 798.4 & 536.4 & 464.5 \\
\hline A. pycnantha & 613.5 & 919.7 & 80.3 & 178.0 & 520.5 & 345.3 & 175.2 & 80.6 & 264.7 & 591.2 & 395.3 & 120.5 \\
\hline Cynara scolymus & 702.3 & 821.7 & 178.3 & 81.7 & 351.0 & 230.4 & 120.6 & 201.5 & 28.9 & 594.4 & 376.0 & 23.1 \\
\hline Punica granatum & 784.9 & 967.4 & 32.6 & 48.1 & 301.6 & 109.5 & 192.1 & 40.9 & 68.6 & 799.2 & 517.9 & 50.9 \\
\hline Phoenix dactilefera & 932.7 & 833.4 & 166.6 & 95.8 & 533.8 & 353.7 & 180.1 & 126.0 & 127.7 & 585.9 & 351.3 & 170.4 \\
\hline
\end{tabular}

DM: Dry Matter, OM: Organic Matter, CP: Crude Protein, NDF: Neutral Detergent Fiber, ADF: Acid Detergent Fiber, ADL: Acid Detergent Lignin, TP: Total phenols, TT: Total tannins, TCT: Total Condensed Tannins.

Table 2. In vitro tannins effects on fermentation characteristics.

\begin{tabular}{|c|c|c|c|c|c|c|c|c|c|c|c|c|c|c|c|c|}
\hline \multirow{3}{*}{ Item } & \multicolumn{7}{|c|}{-PEG } & \multicolumn{7}{|c|}{+ PEG } & \multirow{3}{*}{ SEM } & \multirow{3}{*}{ p-value } \\
\hline & \multicolumn{4}{|c|}{ Plants } & \multicolumn{3}{|c|}{ Plant by-products } & \multicolumn{4}{|c|}{ Plants } & \multicolumn{3}{|c|}{ Plant by-products } & & \\
\hline & A. horrida & $\begin{array}{c}A . \\
\text { gyanophylla }\end{array}$ & A. dealbata & $\begin{array}{c}A . \\
\text { pycnantha }\end{array}$ & $\begin{array}{c}\text { Cynara } \\
\text { scolymus }\end{array}$ & $\begin{array}{c}\text { Punica } \\
\text { granatum }\end{array}$ & $\begin{array}{c}\text { Phoenix } \\
\text { dactilfferal }\end{array}$ & A. horrida & $\begin{array}{c}A . \\
\text { cyanophylla }\end{array}$ & $\begin{array}{c}A . \\
\text { dealbata }\end{array}$ & $\begin{array}{c}A . \\
\text { pycnantha }\end{array}$ & $\begin{array}{c}\text { Cynara } \\
\text { scoymus }\end{array}$ & $\begin{array}{c}\text { Punica } \\
\text { granatum }\end{array}$ & $\begin{array}{c}\text { Phoenix } \\
\text { dactilfferal }\end{array}$ & & \\
\hline $\begin{array}{c}\mathrm{GP}(\mathrm{ml} / \mathrm{g} \\
\mathrm{OM})\end{array}$ & $54.51^{\mathrm{b}}$ & $61.12^{\mathrm{b}}$ & $29.60^{\mathrm{b}}$ & $60.91^{b}$ & $159.81^{\mathrm{a}}$ & $73.67 \mathrm{~b}$ & $70.21^{b}$ & $104.94^{b}$ & $86.02^{\mathrm{b}}$ & $91.81^{\mathrm{b}}$ & $72.49^{\mathrm{b}}$ & $203.99 a$ & $83.89^{\mathrm{b}}$ & $70.69^{\mathrm{b}}$ & 5.02 & $<0.0001$ \\
\hline $\begin{array}{c}\mathrm{CH}_{4}(\mathrm{ml} / \mathrm{g} \\
\mathrm{OM})\end{array}$ & $25.49^{\mathrm{a}}$ & $22.58^{\mathrm{a}}$ & $25.75^{\mathrm{a}}$ & $20.73^{a}$ & $33.57^{\mathrm{a}}$ & $32.28^{\mathrm{a}}$ & $24.86^{\mathrm{a}}$ & $24.51^{\mathrm{a}}$ & $26.61^{\mathrm{a}}$ & $31.17^{\mathrm{a}}$ & $32.04^{a}$ & $28.73^{\mathrm{a}}$ & $36.31^{\mathrm{a}}$ & $28.61^{\mathrm{a}}$ & 2.67 & 0.0983 \\
\hline $\begin{array}{c}\mathrm{NH}_{3} \\
\mathrm{mg} / 100 \mathrm{ml}\end{array}$ & $18.97 \mathrm{ab}$ & $17.67 \mathrm{ab}$ & $18.12^{\mathrm{ab}}$ & $20.47^{a}$ & $18.52^{\mathrm{ab}}$ & $14.05^{\mathrm{b}}$ & $17.97 \mathrm{ab}$ & $22.40^{\mathrm{ab}}$ & $21.35^{\mathrm{ab}}$ & $25.95^{\mathrm{ab}}$ & $27.45^{\mathrm{a}}$ & $14.25^{\mathrm{ab}}$ & $14.90^{\mathrm{b}}$ & $20.37 \mathrm{ab}$ & 2.28 & 0.0382 \\
\hline $\begin{array}{c}\text { VFA mM/g } \\
\text { OM }\end{array}$ & $49.68^{\mathrm{b}}$ & $51.83^{\mathrm{ab}}$ & $37.33^{\mathrm{bc}}$ & $48.00^{\mathrm{bc}}$ & $72.18^{a}$ & $51.85^{\mathrm{b}}$ & $44.15^{\mathrm{c}}$ & $58.46^{\mathrm{b}}$ & $54.38^{\mathrm{bc}}$ & $54.80^{\mathrm{bc}}$ & $55.06^{\mathrm{bc}}$ & $68.08^{\mathrm{a}}$ & $57.85^{\mathrm{b}}$ & $45.73^{c}$ & 2.42 & 0.0009 \\
\hline Acetate $\%$ & $33.05^{\mathrm{b}}$ & $36.21^{\mathrm{b}}$ & $24.67^{c}$ & $33.54^{\mathrm{b}}$ & $48.82^{\mathrm{a}}$ & $33.61^{b}$ & $30.25^{c}$ & $37.63^{\mathrm{b}}$ & $38.62^{\mathrm{b}}$ & $35.48^{c}$ & $37.37^{\mathrm{b}}$ & $46.24^{a}$ & $37.36^{\mathrm{b}}$ & $31.40^{c}$ & 1.59 & $<0.0001$ \\
\hline $\begin{array}{c}\text { Propionate } \\
\%\end{array}$ & $11.7^{\mathrm{ab}}$ & $10.80^{\mathrm{bc}}$ & $8.22^{\mathrm{bc}}$ & $9.77 \mathrm{bc}$ & $14.72^{\mathrm{a}}$ & $11.49^{\mathrm{ab}}$ & $7.78^{c}$ & $14.06^{\mathrm{ab}}$ & $9.70^{\mathrm{bc}}$ & $11.92^{\mathrm{bc}}$ & $11.26^{\mathrm{bc}}$ & $14.35^{\mathrm{a}}$ & $12.80^{\mathrm{ab}}$ & $7.98^{c}$ & 1.55 & 0.1024 \\
\hline Butyrate $\%$ & $2.66^{\mathrm{b}}$ & $2.53^{\mathrm{b}}$ & $2.47^{b}$ & $2.67^{\mathrm{b}}$ & $4.82^{a}$ & $4.63^{a}$ & $3.57^{\mathrm{ab}}$ & $3.47^{\mathrm{b}}$ & $3.17^{\mathrm{b}}$ & $3.85^{\mathrm{b}}$ & $3.32^{\mathrm{b}}$ & $4.23^{\mathrm{a}}$ & $5.13^{a}$ & $3.65^{\mathrm{ab}}$ & 0.92 & 0.0373 \\
\hline $\begin{array}{c}\text { Isobutyrate } \\
\%\end{array}$ & $0.89^{a}$ & $0.87^{a}$ & $0.80^{a}$ & $0.64^{a}$ & $1.26^{\mathrm{a}}$ & $0.64^{\mathrm{a}}$ & $0.95^{\mathrm{a}}$ & $1.26^{\mathrm{a}}$ & $0.84^{a}$ & $1.24^{a}$ & $1.07^{\mathrm{a}}$ & 1.14 & 1.00 & 1.03 & 0.52 & 0.0046 \\
\hline Valerate $\%$ & $0.47^{\mathrm{b}}$ & $0.5^{\mathrm{b}}$ & $0.38^{\mathrm{b}}$ & $0.41^{\mathrm{b}}$ & $1.22^{\mathrm{a}}$ & $0.57^{\mathrm{b}}$ & $0.43^{\mathrm{b}}$ & $0.72^{\mathrm{b}}$ & $0.77^{\mathrm{b}}$ & $0.85^{\mathrm{b}}$ & $0.67^{\mathrm{b}}$ & $1.08^{a}$ & $0.59^{\mathrm{b}}$ & $0.49^{\mathrm{b}}$ & 0.36 & $<0.0001$ \\
\hline $\begin{array}{c}\text { Isovalerate } \\
\%\end{array}$ & $0.89 a$ & $0.88 \mathrm{a}$ & $0.77 \mathrm{a}$ & $0.94 \mathrm{a}$ & $1.32 \mathrm{a}$ & $0.89 \mathrm{a}$ & $1.14^{a}$ & $1.29^{a}$ & $1.27^{\mathrm{a}}$ & $1.42^{\mathrm{a}}$ & $1.34^{a}$ & $1.02^{\mathrm{a}}$ & $0.95^{\mathrm{a}}$ & $1.17^{\mathrm{a}}$ & 0.52 & 0.0032 \\
\hline $\mathrm{C}_{2}: \mathrm{C}_{3}$ & 2.82 & 3.35 & 3.00 & 3.43 & 3.32 & 2.93 & 3.89 & 2.68 & 3.98 & 2.98 & 3.32 & 3.22 & 2.92 & 3.93 & & \\
\hline
\end{tabular}

PEG: Polyethylene Glycol, GP: Gas Production, $\mathrm{CH}_{4}$ :Methane, N-NH 3 :Ammonia,VFA:Volatile Fatty Acids, $\mathrm{C}_{2}: \mathrm{C}_{3}$ : Acetate:Propionate, SEM: Standard Error Mean, Means in the same row with different superscript letters differ $(p<0.05)$. 

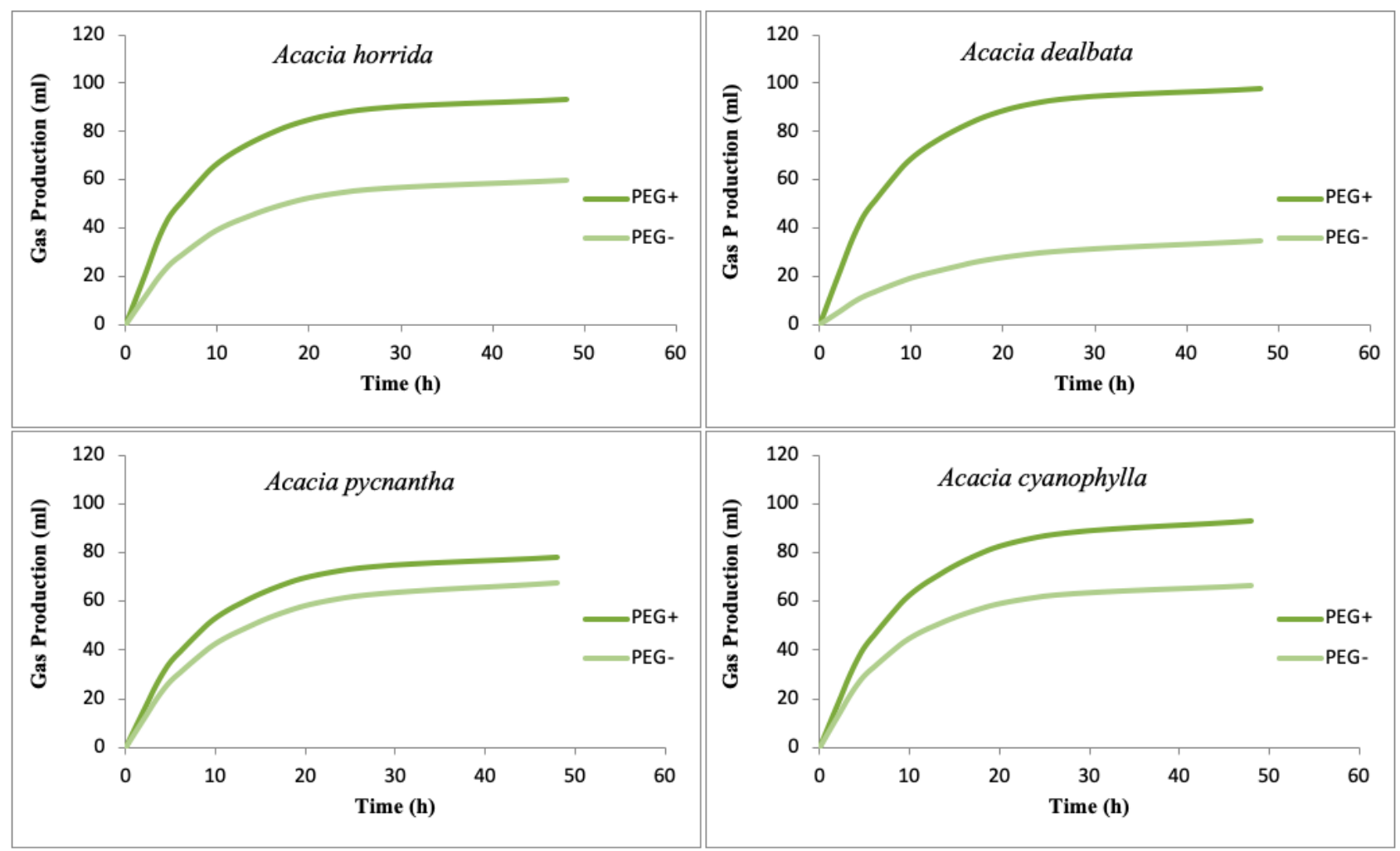

Figure 1. Gas production profile of plants in presence and absence of PEG.
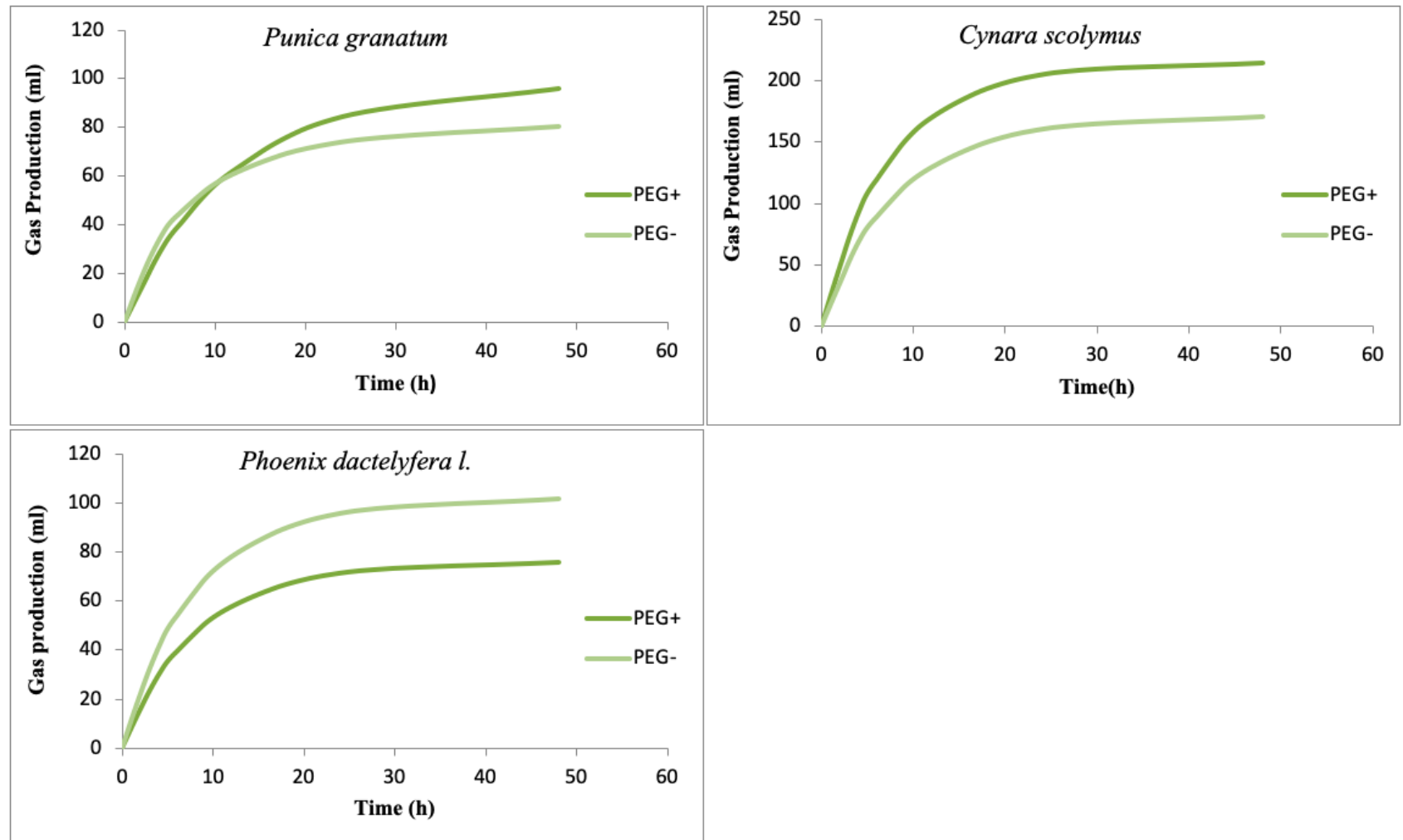

Figure 2. Gas production profile of plant by-products in presence and absence of PEG. 
Results showed that tannins affected $\mathrm{CH}_{4}$ production in different ways. This effect is mainly independent of tannins concentrations. Our finding was in disagreement with Rira et al., (2015). These authors recorded that $\mathrm{CH}_{4}$ production was reduced by $37.5 \%$ and $56.25 \%$ with incorporation of A. cyanophylla tannins by $30 \%$ and $60 \%$, respectively. However, similar results were noted by Gemeda and Hassen (2015), these authors reported that tannins of nineteen tanniferous browse plants reduced methane production. In our study, it appears that tannins structure was more responsible of their biological activity than their concentration (Arhab et al., 2009; Rodriguez et al., 2014). This observation was confirmed by the result obtained in A. horrida (-3.84\%); this plant had the highest condensed tannins content but had no effect on $\mathrm{CH}_{4}$ production. Such finding was similar to that recorded by Bhatta et al., (2012), these authors reported that T. chebula with the highest TT content, showed the lowest reduction of methane production.

Tannins act through two mechanisms to decrease $\mathrm{CH}_{4}$ produced by ruminants: (i) indirectly through a reduction of fiber digestion, which reduce $\mathrm{H}_{2}$ production; and (ii) directly through suppression of methanogens (Wanapat et al., 2013). In the present study, reduction of $\mathrm{CH}_{4}$ production was likely the result of a decrease in fiber degradation by bacteria consortium in the ruminant rumen.

\section{Effect of tannins on fermentation parameters Ammonia production}

The effect of tannins on ruminal fermentation parameters are demonstrated in Table 2. It indicated that ammonia $\left(\mathrm{N}-\mathrm{NH}_{3}\right)$ production was significantly decreased by tannins $(\mathrm{p}=0.0382)$. The highest decrease was noted in $A$. dealbata $(43.2 \%)$ and the lowest in grenade peel $(6.0 \%)$. This effect can be due to the formation of tannins- proteins complexes which inhibit proteins degradation and reduce ammonia production. Bhatta et al. (2014) reported a reduction in $\mathrm{N}-\mathrm{NH}_{3}$ production in samples containing CT and hydrolysable tannins (HT).

Tannins are characterized by their ability to bind to proteins trough hydrogen bonds and hydrophobic interactions. This property of tannins can be attributed to the presence of great number of hydroxyl groups (Martinez et al., 2004;
Shimada, 2006). In the rumen, where $\mathrm{pH}$ is neutral, proteins cannot be cleaved from these bonds, so they are not degraded by microorganisms, thus, CT reduce ammonia production. In the abomasums where the $\mathrm{pH}$ is acidic (2-3), some of the tannin-protein bonds are split and consequently proteins can be broken down into amino acids and then absorbed into the intestine (Piñeiro-Vázquez et al., 2015). Furthermore, tannins can reduce ammonia production by inhibiting growth of proteolytic bacteria (Patra and Saxena, 2010; Hao et al., 2011). Molan et al. (2001) demonstrated that CT from $L$. corniculatus and L. pedunculatus have inhibited the growth of proteolytic rumen bacteria in vitro. Otherwise, ammonia reduction can be caused by proteolityc enzymes deactivation (Makkar, 2003). Effectively, Nsahlalai et al. (2011) reported that tannins from Acacia sieberiana and Acacia nilotica have depressed protein digestibility in the rumen by deactivating of proteolytic enzymes.

\section{Volatile fatty acids (VFA) production}

The impact of tannins on total and individual volatile fatty acids production is also demonstrated in Table 2. This effect was statistically significant $(\mathrm{P}<0.001)$. The highest increase of total volatile fatty acids production after PEG inclusion was noted in $A$. horrida $(58.4 \%)$ and the lowest in date palm leaves $(3.57 \%)$.

Except for C. scolymus, tannins affected acetate production $(\mathrm{P}<0.0001)$. It was increased when PEG was added; the highest increment was recorded in $A$. dealbata (43.8\%) and the lowest in date palms leaves (3.8\%). Likewise, tannins affected propionate production. The highest increments were recorded in $A$. borrida, $A$. dealbata, and $A$. pycnantha. Despite that this effect was statistically not significant $(\mathrm{P}>0.05)$. The impact of tannins was significantly different for butyrate and valerate productions $(\mathrm{P}<005)$.

The reduction of total and individual VFA concentrations was comparable to the findings recorded by Rodriguez et al. (2014) and Tiemann et al. (2008). This reduction is due to tannins inhibition of fiber degradation. These results are consistent with those of methane production; inhibition of fiber degradation diverted VFA profile from acetate and resulted in less hydrogen 
and lower methane production (Bhatta et al., 2012).

There is an inverse relationship between the acetate: propionate $\left(\mathrm{C}_{2}: \mathrm{C}_{3}\right)$ ratio and VFA and $\mathrm{CH}_{4}$ production (Tavendale et al., 2005). However, in our study the ratio $\mathrm{C}_{2}: \mathrm{C}_{3}$ was not influenced and propionate production was decreased in the absence of PEG. These results were in disagreement with other studies. Rira $e t$ al. (2015) noted an increase in the propionate concentration with $A$. gyanopbylla supplementation. Bhatta et al. (2009) also reported an increase in propionate production with supplementation of $\mathrm{CT}$ from quebracho and mimosa.

\section{Impact of $A$. horrida purified tannins on in vitro fermentation}

The effects of $A$. borrida purified tannins incubated with two different forages: alfalfa hay and barley straw at three different concentrations: 50,100 and $150 \mathrm{mg} / \mathrm{g}$ DM on fermentation parameters are represented in Table 3 . The results indicated that $A$. horrida purified tannins had no effect on fermentation parameters except GP. This parameter was decreased with all purified tannins doses compared to the control. The higher decrease was observed for the low concentration $(50 \mathrm{mg} / \mathrm{g} \mathrm{DM})$. These results are different from those reported by Hassanat and Benchaar (2012), these authors studied the effect of purified tannins from $A$. mearnsii at 20, 50 and100 $\mathrm{mg} / \mathrm{g} \mathrm{DM}$ and reported that tannins concentration $\geq 50 \mathrm{mg} / \mathrm{g}$ reduced gas and methane production as well $\mathrm{N}-\mathrm{NH}_{3}$ and branched-chain VFA concentrations. Tiemann et al. (2008) also recorded lower GP and VFA concentration when purified tannins from tropical shrub legumes were added to forage at 25, 50, 75 and $100 \mathrm{mg} / \mathrm{g}$ DM. Likewise, Rira et al. (2015) noted that methane,VFA and fermented organic matter were decreased as tannins concentrations increased. Moreover, tannins effects may appear with lower concentration. In two separate studies conducted by Tan et al. (2011) and Huang et al. (2010) on Leucaena leucocephala, the concentration of gas, $\mathrm{CH}_{4}$ and VFA were reduced at 0-30 mg/g DM, 20-50 mg/g $\mathrm{DM}$, respectively. However, Jayanegara et al. (2011) in a meta-analysis reported that tannins effects can only be predicted from concentration level >20 mg / g DM.

In the current study, the absence of tannins effects on the different fermentation parameters may be due to many factors other than concentration such as tannins source, chemical structure and polymerization degree. Indeed several authors documented varying biological effects at the same concentration of tannins from different sources (Tiemann et al., 2008; Hassanat and Benchaar, 2012; Rira et al., 2015). This situation was also supported by the work carried out by Gatechew et al. (2008), these authors studied the effect of supplementation of quebracho, tannic acid and gallic to alfalfa and reported that tannins effects on rumen fermentation and protein degradation did not only depend on their concentration but also on their type. Huyen et al. (2016) studied the effect of CT polymerization degree of eight plants extracts and found that the proportion of prodelphinidins had the greatest effect on fermentation pattern followed by average polymer size and percentage of cis-flavan-3-ols.

Tannins are characterized by their high molecular weight (MW) which can play an important role in their biological activity. In this context, Saminathan et al. (2014) have demonstrated that the effect of CT with high MW on $\mathrm{CH}_{4}$ production was higher than other $\mathrm{CT}$ fractions extracted from Leucaena leucocephala. Likewise, Huang et al. (2011) noted that the highest inhibition of $\mathrm{CH}_{4}$ production was recorded in the fraction with the highest MW. In the present study, our purified tannins may not have the appropriate MW or polymerization degree that allows them to decrease methane, VFA or ammonia production. These suggestions need to be confirmed through the determination of the structure of our purified condensed tannins. The determination of the structure should clarify the various structural details responsible for the effects recorded in our study. 
Table 3. In vitro $A$. horrida purified tannins Effects on fermentation characteristics.

\begin{tabular}{|c|c|c|c|c|c|c|c|c|c|c|c|c|c|}
\hline \multirow{3}{*}{ Item } & \multicolumn{6}{|c|}{ Alfalfa hay forage } & \multirow{3}{*}{ Item } & \multicolumn{6}{|c|}{ Barley straw forage } \\
\hline & \multicolumn{4}{|c|}{ Dose (mg/g DM) } & \multirow{2}{*}{ SEM } & \multirow{2}{*}{$P$ value } & & \multicolumn{4}{|c|}{ Dose (mg/g DM) } & \multirow{2}{*}{ SEM } & \multirow{2}{*}{ P value } \\
\hline & $\mathbf{0}$ & 50 & 100 & 150 & & & & $\mathbf{0}$ & 50 & 100 & 150 & & \\
\hline $\begin{array}{c}\text { Gas (ml/g } \\
\text { OM) }\end{array}$ & $479.10^{a}$ & $21.17 \mathrm{a}$ & $166.85^{a}$ & $327.52^{\mathrm{a}}$ & 5.03 & 0.9704 & $\begin{array}{c}\text { Gas } \\
(\mathrm{ml} / 24 \mathrm{~h})\end{array}$ & $350.50 \mathrm{a}$ & $67.62^{a}$ & $172.65^{\mathrm{a}}$ & $280.07 a$ & 5.46 & 0.9993 \\
\hline $\begin{array}{c}\mathrm{CH}_{4}(\mathrm{ml} / \mathrm{g} \\
\mathrm{OM})\end{array}$ & $31.03^{a}$ & $37.41^{a}$ & $35.90^{a}$ & $41.64^{a}$ & 2.80 & 0.2912 & $\begin{array}{c}\mathrm{CH}_{4} \\
(\mathrm{ml} / 24 \mathrm{~h})\end{array}$ & $27.94^{a}$ & $29.28^{a}$ & $31.60^{a}$ & $32.05^{a}$ & 2.63 & 0.9130 \\
\hline $\begin{array}{c}\mathrm{N}-\mathrm{NH}_{3} \\
(\mathrm{mg} / 100 \mathrm{ml})\end{array}$ & $23.67^{a}$ & $25.52^{\mathrm{a}}$ & $27.21^{\mathrm{a}}$ & $26.25^{a}$ & 2.33 & 0.9168 & $\begin{array}{c}\mathrm{N}-\mathrm{NH}_{3} \\
(\mathrm{mg} / 100 \mathrm{ml})\end{array}$ & $18.10^{\mathrm{a}}$ & $19.72^{\mathrm{a}}$ & $19.59^{a}$ & $21.82^{\mathrm{a}}$ & 2.23 & 0.8854 \\
\hline $\begin{array}{c}\mathrm{VFA} \\
(\mathrm{mM} / \mathrm{g} \\
\mathrm{OM})\end{array}$ & $68.24^{a}$ & $69.04^{a}$ & $70.52^{\mathrm{a}}$ & $68.09^{\mathrm{a}}$ & 2.61 & 0.9164 & $\begin{array}{l}\text { Total VFA } \\
(\mathrm{mM})\end{array}$ & $51.81^{\mathrm{a}}$ & $52.66^{\mathrm{a}}$ & $51.55^{\mathrm{a}}$ & $50.19^{a}$ & 3.42 & 0.9976 \\
\hline Acetate $\%$ & $44.49^{a}$ & $44.98^{a}$ & $45.92^{\mathrm{a}}$ & $44.49^{a}$ & 2.34 & 0.9600 & Acetate $\%$ & 33.87 a & $34.48^{a}$ & $33.64^{a}$ & $32.99^{a}$ & 2.86 & 0.9988 \\
\hline $\begin{array}{c}\text { Propionate } \\
\%\end{array}$ & $13.46^{a}$ & $13.65^{a}$ & $13.98^{a}$ & $13.53^{a}$ & 0.91 & 0.6037 & $\begin{array}{c}\text { Propionate } \\
\%\end{array}$ & $10.00^{a}$ & $10.01^{a}$ & $9.74^{a}$ & $9.73^{a}$ & 1.33 & 0.9951 \\
\hline Butyrate $\%$ & $6.09^{a}$ & $6.23^{a}$ & $6.42^{a}$ & $6.17^{a}$ & 1.04 & 0.9631 & Butyrate $\%$ & $5.00^{\mathrm{a}}$ & $5.08^{a}$ & $4.97^{a}$ & $5.00^{\mathrm{a}}$ & 1.23 & 0.9995 \\
\hline $\begin{array}{c}\text { Isobutyrate } \\
\% \%\end{array}$ & $1.31^{\mathrm{a}}$ & $1.22^{\mathrm{a}}$ & $1.20^{a}$ & $1.12^{\mathrm{a}}$ & 0.30 & 0.1142 & $\begin{array}{c}\text { Isobutyrate } \\
\% \%\end{array}$ & $0.92^{a}$ & $0.96^{\mathrm{a}}$ & $1.01^{\mathrm{a}}$ & $0.95^{\mathrm{a}}$ & 0.37 & 0.9188 \\
\hline Valerate $\%$ & $1.20^{\mathrm{a}}$ & $1.22^{\mathrm{a}}$ & $1.25^{\mathrm{a}}$ & $1.11^{\mathrm{a}}$ & 0.48 & 0.9456 & Valerate $\%$ & $0.72^{\mathrm{a}}$ & $0.76^{\mathrm{a}}$ & $0.74^{a}$ & 0.69 a & 0.43 & 0.9831 \\
\hline $\begin{array}{c}\text { Isovalerate } \\
\%\end{array}$ & $1.66^{a}$ & $1.71^{\mathrm{a}}$ & $1.73^{\mathrm{a}}$ & $1.65^{\mathrm{a}}$ & 0.47 & 0.9878 & $\begin{array}{c}\text { Isovalerate } \\
\%\end{array}$ & $1.28^{\mathrm{a}}$ & $1.36^{a}$ & $1.43^{a}$ & $1.24^{\mathrm{a}}$ & 0.55 & 0.9209 \\
\hline $\mathrm{C}_{2}: \mathrm{C}_{3}$ & 3.31 & 3.29 & 3.28 & 3.29 & & & $\mathrm{C}_{2}: \mathrm{C}_{3}$ & 3.38 & 3.44 & 3.45 & & & \\
\hline
\end{tabular}

GP: Gas Production, CH4: Methane, N-NH3: Ammonia, VFA: Volatile Fatty Acids, $\mathrm{C}_{2}: \mathrm{C}_{3}$ :Acetate:Propionate, SEM: Standard Error Mean, Means in the same row with different superscript letters differ $(p<0.05)$. 


\section{CONCLUSIONS}

According to the present results, the supplementation of $A$. horrida purified tannins extract to two different forages at different concentrations did not cause significant changes in fermentation parameters and methane production in vitro, despite that this plant presents high condensed tannin content. This suggests, as was previously reported by other studies conducted on different tannins sources, that effects of tannins may be strongly linked to their structure and their molecular weight more than to their concentration. For this reason, it is interesting that this work may be completed by physical characterization of these tannins. Moreover, comprehensive in vivo studies have to be executed to evaluate the effects of these tannins and to better understand their action mechanism.

\section{ACKNOWLEDGEMENTS}

Authors gratefully acknowledge Isabel Jiménez Romero from (EEZ, CSIC, Granada, Spain) for her technical assistance.

\section{REFERENCES}

Abdallah Hassan Sallam, S. M., Da Silva Bueno, I. C., De Godoy, P. B., Nozella, E.F., Silber Schmidt Vitti, D. M., \& Abdalla, A. L. 2010. Ruminal fermentation and tannins bioactivity of some browses using a semi-automated gas production technique. Tropical and Subtropical Agroecosystems 12: 1-10.

Abebe, A., Tolera, A., Holand, O., Ådnøy, T., \& Eik, L. O. 2012. Seasonal variations in nutritive value of some browse and grass species in Borana rangeland, Southern Ethiopia. Tropical and Subtropical Agroecosystems 15(2): 261-271.

Al-Soqeer, A. A. 2008. Nutritive value assessment of Acacia species using their chemical analyses and in vitro gas production technique. Research journal of agriculture and biological sciences 4 (6): 688-694.

AOAC, 1990. Official Methods of analysis, 15th ed. Association of Official Analytical Chemists, AOAC, Arlington, VA.

Arco-Pérez, A., Ramos-Morales, E., Yáñez-Ruiz, D. R., Abecia, L., \& Martín-García, A. I. 2017. Nutritive evaluation and milk quality of including of tomato or olive by-products silages with sunflower oil in the diet of dairy goats. Animal Feed Science and Technology 232: 57-70.

Arhab, R., Macheboeuf, D., Aggoun, M., Bousseboua, H., Viala, D., \& Besle, J. M. 2009. Effect of polyethylene glycol on in vitro gas production and digestibility of tannin containing feedstuffs from North African arid zone. Tropical and Subtropical Agroecosystems 10: 475- 486.

Ben Salem, H., Nefzaoui, A., Ben Salem, L., \& Tisserand, J. L.1997. Effect of Acacia on intake and cyanophylla Lindl. foliage supply digestion by sheep fed lucerne hay-based diets. Animal Feed Science and Technology 68: 101-113.

Ben Salem, H., Nefzaoui, A., Ben Salem, L., \& Tisserand, J. L. 1999. Different means of administering polyethylene glycol to sheep: effect on the nutritive value of Acacia cyanophylla Lindl. foliage. Animal Science Journal 68: 809-818.

Bhatta, R, Uyeno, Y., Tajima, K., Takenaka, A., Yabumoto, Y., Nonaka, I., Enishi, O., \& Kurihara, M. 2009. Difference in the nature of tannins on in vitro ruminal methane and volatile fatty acid production and on methanogenic archaea and protozoal populations. Journal of Dairy Science 92(11): 5512-5522.

Bhatta, R., Baruah, L., Saravanan, M., Suresh, K. P., \& Sampath, K. T. 2012. Effect of medicinal and aromatic plants on rumen fermentation, protozoa population and methanogenesis in vitro. Journal of Animal Physiology and Animal Nutrition 97 (3): 446-456.

Bhatta, R., Saravanan, M., Baruah, L., \& Prasad, C. S. 2014. Effects of graded levels of tannin-containing tropical tree leaves on in vitro rumen fermentation, total protozoa and methane production. Journal of Applied Microbiology 118 (3): 557-564.

Boufennara, S., Bouazza, L., De Vega, A., Fondevila, M., Amanzougarene, Z., \& Lopez, S. 2016. In vitro assessment of nutritive value of date palm by-products as feed for ruminants. Emirates Journal of Food and Agriculture 28(10): 695-703.

Bravo, L. 1998. Polyphenols: Chemistry, Dietary Sources, Metabolism, and Nutritional Significance. Nutrition Reviens 56 (11): 317-333.

Fikri Benbrahim, K., Berrada, H., El Ghachtouli, N., \& Ismaili, M. 2014. Acacia: Promising nitrogen fixing trees for sustainable development in arid and semi-arid areas. International Journal of Innovation and Applied Studies 8 (1): 46-58.

France, J., Dijkstra, J., Dhanoa, M., Lopez S., \& Bannink, A. 2000. Estimating the extent of degradation of ruminant feeds from a description of their gas production profiles observed in vitro: derivation of models and other mathematical considerations. British Journal of Nutrition 83 (02): 143-150.

Frutos, P., Hervás, G., Giráldez F.-J., \& Mantecón, A.-R. 2004. Review. Tannins and ruminant nutrition Tannins: structure and chemical. Spanish Journal of Agricultural Research 2(2): 191 202.

Gemeda, B. S., Hassen, A. 2015. Effect of tannin and species variation on in vitro digestibility, gas, and methane production of tropical browse plants. Asian Australasian Journal of Animal Sciences 28(2): 188-199.

Getachew, G., Pittroff, W., Putnam, D. H., Dandekar, A., Goyal, S., \& De Peters, E. J. 2008. The influence of addition of gallic acid, tannic acid, or quebracho tannins to alfalfa hay on in vitro rumen fermentation and microbial protein synthesis. Animal Feed Science and Technology 140 (3-4): 444 461.

Goel, G., Puniya, A. K., Singh K., \& Aguilar, C. N. 2005 Interaction of gut microflora with tannins in feeds. Naturwissenschaften 92(11): 497-503.

Grainger, C., Clarke, T., Auldist, M. J., Beauchemin, K. A., McGinn S. M., Waghorn G. C., \& Eckard, R. J. 2009. Potential use of Acacia mearnsii condensed tannins to reduce methane emissions and nitrogen excretion from grazing dairy cows. Canadian Journal of Animal Science 89 (2): 241-251.

Guerrero, M., Cerrillo-Soto, M. A., Ramirez, R. G., Salem, A. Z. M., González, H., \& Juárez-Reyesa, A. S. 2012. Influence of polyethylene glycol on in vitro gas production profiles and 
microbial protein synthesis of some shrub species. Animal Feed Science and Technology 176(1-4): 32- 39.

Hanafy, M. A., Abdul Aziz, G. M., Fayed, A., \& Ghandour M. M. 2014. In vitro evaluation of using tannins deactivation materials in Acacia saligna and Tamrix aphylla. Egyptian Journal of Nutrition and Feeds 17(1): 43-50.

Hao, X., Benke, M. B., Li, C., Larney, F. J., Beauchemin, K. A., \& Mcallister T. A. 2011. Nitrogen transformation and greenhouse gas emissions during composting of manure from cattle fed diets containing corn dried distillers grains with solubles and condensed tannins. Animal Feed Science and Technology 166-167: 539-549.

Hassanat F., Benchaar C. 2012. Assessment of the effect of condensed (acacia and quebracho) and hydrolysable (chestnut and valonea) tannins on rumen fermentation and methane production in vitro. Journal of the Science of Food and Agriculture 93 (2): 332-339.

Hatew, B., Stringano, E., Mueller-Harvey, I., Hendriks, W. H., Hayot Carbonero, C., Smith, L. M. J., \& Pellikaan,W. F. 2016. Impact of variation in structure of condensed tannins from sainfoin (Onobrychis viciifolia) on in vitro ruminal methane production and fermentation characteristics. Journal of Animal Physiology and Animal Nutrition 100 (2016): 348-360.

Huang, X. D., Liang, J. B., Tan, H. Y., Yahya, R., Khamseekhiew, B., \& Ho, Y. W. 2010. Molecular weight and protein binding affinity of Leucaena condensed tannins and their effects on in vitro fermentation parameters. Animal Feed Science and Technology 159(3-4): 81-87.

Huang, X. D., Liang, J. B., Tan, H. Y., Yahya, R., \& Ho, Y. W. 2011. Effects of Leucaena condensed tannins of differing molecular weights on in vitro $\mathrm{CH}_{4}$ production. Animal Feed Science and Technology 166- 167: 373-376.

Huyen, N. T., Fryganas, C., Uittenbogaard, G., Muller-Harvey, I., Verstegen, M. W. A., Hendriks, W. H., \& Pellikaan, W. F. 2016. Structural features of condensed tannins affect in vitro ruminal methane production and fermentation characteristics. Journal of Agricultural Science 154(08): 14741487.

Jayanegara, A., Leiber, \& F., Kreuzer, M. 2011. Meta-analysis of the relationship between dietary tannin level and methane formation in ruminants from in vivo and in vitro experiments. Journal of Animal Physiology and Animal Nutrition 96 (3): 365 375.

Krueger, W. K., Gutierrez-Banuelos, H., Carstensa, G. E., Min, B. R., Pinchak, W. E., Gomez, R. R., Anderson, R. C., Krueger, N. A., \& Forbes T. D. A. 2010. Effects of dietary tannin source on performance, feed efficiency, ruminal fermentation, and carcass and non-carcass traits in steers fed a high-grain diet. Animal Feed Science and Technology 159 (1-2): 1-9.

Liu, H., Vaddella, V., \& Zhou, D. 2011. Effects of chestnut tannins and coconut oil on growth performance, methane emission, ruminal fermentation, and microbial populations in sheep. Journal of Dairy Science 94(12): 6069-6077.

Makkar, H. P. S., Bluemmel, M., Borowy, N. K., \& Becker, K. 1993. Gravimetric determination of tannins and their correlations with chemical and protein precipitation methods. Journal of the Science of Food and Agriculture 61(2): 161-165.

Makkar, H.P.S., Blummel, M., \& Becker, K. 1995. Formation of complexes between polyvinyl pyrrolidones or polyethylene glycols and tannins, and their implication in gas production and true digestibility in in vitro techniques. British Journal of Nutrition 73 (06): 897-913.

Makkar, H. P. S. 2003. Effects and fate of tannins in ruminant animals, adaptation to tannins, and strategies to overcome detrimental effects of feeding tannin-rich feeds. Small Ruminant Research 49(3): 241-256.

Makkar, H. P. S. 2005. In vitro gas methods for evaluation of feeds containing phytochemicals. Animal Feed Science and Technology 123-124: 291-302.

Martinez, T. F., Moyano, F. J., Diaz, M., Barroso, F. G., \& Alarcon, F. J. 2004. Ruminal degradation of tannin-treated legume meals. Journal of the Science of Food and Agriculture 84 (14): 1979-1987.

Melesse, A., Steingass, H., Schollenberge, M., \& Rodehutscord, M. 2017. Screening of common tropical grass and legume forages in Ethiopia for their nutrient composition and methane production profile in vitro. Tropical GrasslandsForrajes Tropicales 5(3): 163-175.

Mezzomo, R., Paulino, P. V. R., Detmann, E., Valadares Filho, S. C., Paulino, M. F., Monnerat, J. P. I. S., Duarte, M. S., Silva, L. H. P., \& Moura L. S. 2011. Influence of condensed tannin on intake, digestibility, and efficiency of protein utilization in beef steers fed high concentrate diet. Livestock Science 141(1): 1-11.

Min, B. R., Attwood, G. T., Reilly, K., Sun, W., Peters, J. S., Barry, T. N., \& McNabb, W. C. 2002. Lotus corniculatus condensed tannins decrease in vivo populations of proteolytic bacteria and affect nitrogen metabolism in the rumen of sheep. Canadian Journal of Microbiology 48(10): 911-921.

Mirzaei-Aghsaghali, A., Maheri-Sis, N., Mansouri, H., Razeghi, M. E., Mirza-Aghazadeh, A., Cheraghi, H., \& AghajanzadehGolshani, A. 2011. Evaluating potential nutritive value of pomegranate prossecing by-products for ruminants using in vitro gas production technique. ARPN Journal of Agricultural and Biological Science 6: 1990-6145.

Molan, A. L., Attwood, G. T., Min, B. R., \& McNabb, W. C. 2001. The effect of condensed tannins from Lotuspedunculatus and Lotus corniculatus on the growth of proteolytic rumen bacteria in vitro and their possible mode of action. Canadian Journal of Microbiology 47: 626-633.

Moujahed, N., Kayouli, C., Thewis, A., Becker, Y., \& Rezgui, S. 2000. Effects of multinutrient blocks and polyethylene glycol 4000 supplies on intake and digestion by sheep fed Acacia cyanophylla Lindl. Foliage-based diets. Animal Feed Science and Technology 88: 219-238.

Naumann, H. D., Tedeschi, L. O., Zeller, W. E., \& Huntley, N. F. 2017. The role of condensed tannins in ruminant animal production: advances, limitations and future directions. Revista Brasileira de Zootecnia 46(12): 929-949.

Naumann, H. D., Sepela, R., Rezaire, A., Masih, S. E., Zeller, W. E., Reinhardt, L. A., Robe, J. T., Sullivan, M. L., \& Hagerman, A. E. 2018. Relationships between structures of condensed tannins from texas legumes and methane production during in vitro rumen digestion. Molecules 23(9): 2123.

Ningrat, R. W. S., Zain, M., Suryani, E., \& Suryani, H. 2016. Effects of doses and different sources of tannins on in vitro ruminal methane, volatile fatty acids production and on bacteria and protozoa populations. Asian Journal of Animal Sciences 11(1): 47-53.

Njida, A. A., Nasiru, A. 2010. In vitro gas production and dry matter digestibility of tannins containing forages of semi-arid region of north eastern Nigeria. Pakistan Journal of Nutrition 9 (1): 60-66.

Nsahlai, I. V., Fon, F. N., \& Basha, N. A. D. 2011. The effect of tannin with and without polyethylene glycol on in vitro gas production and microbial enzyme activity. South African Journal Of Animal Science 41(4): 338-344.

Pascual, J. J., Fernandez, C., Diaz J. R., Garce, C., \& Rubert-Alema, J. 2000. Voluntary intake and in vivo digestibility of different date-palm fractions by Murciano-Granadina (Capra hircus). Journal of Arid Environments 45(2): 183-189. 
Patra, A. K., Saxena, J. 2010. A new perspective on the use of plant secondary metabolites to inhibit methanogenesis in the rumen. Phytochemistry 71: 1198-1222.

Patra, A. K., Saxena, J. 2011. Exploitation of dietary tannins to improve rumen metabolism and ruminant nutrition. Journal of the Science of Food and Agriculture 91 (1): 24-37.

Piñeiro-Vázquez, A. T., Canul-Solís, J. R., Alayón-Gamboa, J. A., Chay-Canul, A. J., Ayala-Burgos, A. J., Aguilar-Pérez, C. F., Solorio-Sánchez, F. J., \& Ku-Vera, J. C. 2015. Potential of condensed tannins for the reduction of emissions of enteric methane and their effect on ruminant productivity. Archivos de Medicina Veterinaria 47(3): 263-272.

Porter, L. J., Hrstich, L. N., \& Chan, B. G. 1986. The conversion of procyanidins and prodelphinidins to cyanidin and delphinidin. Phytochemistry 25(1): 223-230.

Rira, M., Chentli, A., Boufenera, S., \& Bousseboua, H. 2015. Effects of plants containing secondary metabolites on ruminal methanogenesis of sheep in vitro. Energy Procedia 74: 15- 24.

Rira, M., Morgavi, D. P., Archimède, H., Marie-Magdeleine, C., Popova, M., Bousseboua, H., \& Doreau, M. 2015. Potential of tannin-rich plants for modulating ruminal microbes and ruminal fermentation in sheep. Journal of Animal Science 93(1): 334-347.

Rodríguez, R., De la Fuente, G., Gómez, S., \& Fondevila, M. 2014. Biological effect of tannins from different vegetal origin on microbial and fermentation traits in vitro. Animal Production Science 54(8): 1039-1046.

Rubanza, C. D. K., Shemb, M. N., Otsyina, R., Bakengesa, S. S., Ichinohed, T., \& Fujihara, T. 2005. Polyphenolics and tannins effect on in vitro digestibility of selected Acacia species leaves. Animal Feed Science and Technology 119(1-2): 129-142.

Sadq, S. M., Ramzi, D. O. M., Hamasalim, H. J., \& Ahmed, K. A. 2016. Growth performance and digestibility in Karadi lambs receiving different levels of pomegranate peels. Open Journal of Animal Sciences 6: 16-2.

Saminathan, M., Sieo, C. C., Abdullah, N., Vui Ling Wong, C. M., \& Hao, Y. W. 2014. Effects of condensed tannin fractions of different molecular weights from a Leucaena leucocephala hybrid on in vitro methane production and rumen fermentation. Journal of the Science of Food and Agriculture 95 (13): 2742-2749.

Shabtay, A., Eitam, H., Tadmor, Y., Orlov, A., Meir, A., Weinberg, P., Weinberg, Z. G., Chen, Y., Brosh, A., Izhaki, I., \& Kerem, Z. 2008. Nutritive and antioxidative potential of fresh and stored pomegranate industrial byproduct as a novel beef cattle feed. Journal of Agricultural and Food Chemistry 56 (2): 10063-10070.

Shimada, T. 2006. Salivary proteins as a defense against dietary tannins. Journal of Chemical Ecology 32 (6): 1149-1163.

Śliwiński, B. J., Kreuzer, M., Wettstein, H.-R., \& Machmüller, A. 2002. Rumen fermentation and nitrogen balance of lambs fed diets containing plant extracts rich in tannins and saponins, and associated emissions of nitrogen and methane. Archives of animal nutrition 56 (6): 379-392.

Tan, H. Y., Sieo, C. C., Abdullaha, N., Liang, J. B., Huang, X. D., \& Ho, Y. W. 2011. Effects of condensed tannins from Leucaena on methane production, rumen fermentation and populations of methanogens and protozoa in vitro. Animal Feed Science and Technology 169 (3-4): 185- 193.

Tavendale, M. H., Meagher, L. P., Pacheco, D., Walker, N., Attwood, G. T. \& Sivakumaran, S. 2005. Methane production from in vitro rumen incubations with Lotus pedunculatus and Medicago sativa, and effects of extractable condensed tannin fractions on methanogenesis. Animal Feed Science and Tecbnology 123-124: 403-419.
Tefera, S., Mlambo, V., Dlamini, B. J., Dlamini, A. M., Koralagama, K. D. N., \& Mould, F. L. 2008. Chemical composition and in vitro ruminal fermentation of common tree forages in the semi-arid rangelands of Swaziland. Animal Feed Science and Technology 142(1-2): 99-110.

Theodorou, M. K., Williams, B. A., Dhano, M. S., McAllan, A. B., \& France, J. 1994. A simple gas production method using a pressure transducer to determine the fermentation kinetics of ruminant feeds. Animal Feed Science and Technology 48(3-4): 185-197.

Terrill, T. H., Rowan, A. M., Douglas, G. B., \& Barry, T. N. 1992. Determination of extractable and bound condensed tannin concentrations in forage plants, protein concentrates meals and cereal grains. Journal of the Science of Food and Agriculture 58: 321-329.

Tiemann, T. T., Avila, P., Ramirez, G., Lascano, C. E., Kreuzer, M., \& Hess, H. D. 2008. In vitro ruminal fermentation of tanniniferous tropical plants: Plant-specific tannin effects and counteracting efficiency of PEG. Animal Feed Science and Technology 146 (3-4): 222-241.

Van Soest, P. J., Robertson, J. B., \& Lewis, B. A. 1991. Methods for dietary fiber, neutral detergent fiber, and non-starch polysaccharides in relation to animal nutrition. Journal of Dairy Science 74: 3583-3597.

Wanapat, M., Kang, S., \& Polygraph, S. 2013. Development of feeding systems and strategies of supplementation to enhance rumen fermentation and ruminant production in the tropics. Journal of Animal Science and Biotechnology 4(1): 32.

Weatherburn, M. 1967. Phenol-hypochlorite reaction for determination of ammonia. Analytical Chemistry 39(8): 971 974.

Yurtseven, S., Kaya, Z., \& Takim, K. 2018. The effect of pomegranate peel and pistachio hulls on performance and enteric methane emissions in straw-fed lambs (Ovisaries L.). Applied Ecology and Environmental Research 17 (1): 305-316.

Ziaei, N., Sharifi Hosseini, S. M. M. 2009. Feeding value and in vitro digestibility of date-palm leaves supplemented with different supplementary energy. Pakistan Journal of Biological Sciences 12(10):817-820. 